\title{
Nilai-Nilai Kearifan Lokal Tradisi Suran
}

\author{
Valencia Tamara Wiediharto, I Nyoman Ruja, Agus Purnomo \\ agus.purnomo.fis@um.ac.id \\ Universitas Negeri Malang
}

\begin{abstract}
The purpose of this study was to analyze the forms of local wisdom values of the Suran Tradition in Wonosari Village, Wonosari District, Malang Regency. This study uses a qualitative approach with a type of descriptive research. The data sources used are primary data sources and secondary data sources. There are three data collection techniques in the study, namely interviews, observation, and documentation. The conclusion of this study is that the Suran Tradition is a celebration of the Wonosari Village community to welcome the 1st of the Suro Month. The Wonosari Village community has its own ways to preserve the traditions that surround them and is known as local wisdom. The local wisdom in the Suran Tradition is divided into several values, including religious values, aesthetic values, mutual cooperation values, moral values and tolerance values. The values of local wisdom are symbols produced by the community through an interaction process. These values can be interpreted well if the community runs the Suran Tradition routinely every year and understands the values contained in each stage starting from preparation, implementation and closing.
\end{abstract}

Keywords : Value, Local Wisdom, Suran Tradition

\begin{abstract}
Abstrak
Tujuan penelitian ini adalah untuk menganalisis bentuk nilai-nilai kearifan lokal Tradisi Suran di Desa Wonosari Kecamatan Wonosari Kabupaten Malang. Penelitian ini menggunakan pendekatan kualitatif dengan jenis penelitian deskriptif. Sumber data yang digunakan adalah sumber data primer dan sumber data sekunder. Teknik pengumpulan data dalam penelitian ada tiga, yaitu wawancara, observasi, dan dokumentasi. Simpulan penelitian ini adalah Tradisi Suran merupakan perayaan masyarakat Desa Wonosari untuk menyambut tanggal 1 pada Bulan Suro. Masyarakat Desa Wonosari memiliki cara-cara tersendiri untuk melestarikan tradisi yang ada di sekitarnya dan dikenal dengan kearifan lokal. Adapun kearifan lokal yang ada pada Tradisi Suran terbagi menjadi beberapa nilai, diantaranya nilai religi, nilai estetika, nilai gotong royong, nilai moral dan nilai toleransi. Nilai-nilai kearifan lokal tersebut merupakan simbolsimbol yang dihasilkan oleh masyarakat melalui proses interaksi. Nilai-nilai tersebut dapat dimaknai dengan baik apabila masyarakat menjalankan Tradisi Suran secara rutin setiap tahun dan memahami nilai-nilai yang terkandung dalam setiap tahapan mulai dari persiapan, pelaksanaan dan penutupan.
\end{abstract}

Kata kunci: Nilai, Kearifan lokal, Tradisi Suran 
Valencia Tamara Wiediharto, I Nyoman Ruja, Agus Purnomo

Nilai-Nilai Kearifan Lokal Tradisi Suran

\section{Pendahuluan}

Kehidupan masyarakat di Indonesia diwarnai dengan beberapa wujud kebudayaan yang dihasilkan masyarakat. Koentjaraningrat (2016) menjelaskan bahwa kebudayaan dapat digolongkan menjadi tiga wujud; yang pertama sebagai suatu kompleks dari ide, gagasan, nilai, norma dan peraturan; kedua sebagai kompleks aktivitas serta tindakan berpola dari manusia dalam masyarakat; ketiga sebagai bendabenda hasil karya manusia. Berkaitan dengan ketiga wujud kebudayaan tersebut, wujud kedua merupakan wujud yang melekat dalam kehidupan masyarakat sehari-hari. Wujud dari kebudayaan kedua ini berupa tradisi yang diyakini suatu masyarakat. Tradisi di Indonesia berbeda antar daerah satu dengan yang lain, tidak terkecuali pada masyarakat Jawa. Setelah berkembang pesat di lingkungan kerajaan, tradisi ini menyebar di kalangan masyarakat biasa dalam berbagai bentuk kegiatan maupun perilaku spiritual. Tradisi Suran di pandang sebagai sesuatu yang sakral, karena kebanyakan orang mengharap akan mendapatkan berkah besar di hari suci tersebut.

Tradisi Suran di Desa Wonosari Kecamatan Wonosari Kabupaten Malang diadakan setiap satu tahun sekali di bulan Suro, tepatnya pada tanggal 1 Suro. Pelaksanaan Tradisi Suran dipimpin oleh sesepuh dan diikuti oleh seluruh masyarakat Desa Wonosari. Tradisi Suran diadakan mulai tahun 2000, dalam bentuk perayaan besar dan meriah, namun sebelumnya hanya dalam bentuk perayaan sederhana berupa selamatan dan napak tilas oleh sesepuh Desa Wonosari ke puncak Gunung Kawi. Pelaksanaan tradisi berupa arak-arakan yang dimulai dari terminal Desa Wonosari sampai ke Lapangan Pengembangan Wisata Pesarehan Gunung Kawi untuk puncak acara yakni pembakaran Sangkala. Tradisi Suran dihadiri oleh Bupati Malang, yakni untuk mengesahkan pembukaan dan mengikuti acara hingga selesai. Tradisi Suran di Desa Wonosari memiliki makna yang berguna dalam kejawen yang cukup kuat, salah satunya pada tradisi perayaan malam 1 Suro. Tradisi perayaan malam 1 Suro berkembang pada masyarakat Jawa dan salah satunya ada di Desa Wonosari, Kecamatan Wonosari yang terletak di Kabupaten Malang. Perayaan 1 Suro (Muharram) di Desa Wonosari ini dikenal dengan sebutan "Tradisi Suran" .

Suran merupakan adat masyarakat Jawa untuk menyambut tahun baru sesuai penanggalan Jawa (Nurshodiq, 2012). Setelah berkembang pesat di lingkungan kerajaan, tradisi ini menyebar di kalangan masyarakat biasa dalam berbagai bentuk kegiatan maupun perilaku spiritual. Tradisi Suran di pandang sebagai sesuatu yang sakral, karena kebanyakan orang mengharap akan mendapatkan berkah besar di hari suci tersebut. Tradisi Suran di Desa Wonosari unik dan berbeda dengan perayaan Tradisi Suran di daerah-daerah lain. Perayaan Suran tersebut berbeda, karena terdapat nilai-nilai kearifan lokal yang dapat diterapkan dalam kehidupan masyarakat Desa Wonosari, sehingga menjadikan masyarakat menjadi lebih baik dalam hubungan 
dengan Tuhan YME, kehidupan antar sesama, maupun dengan alam. Nilai-nilai kearifan lokal yang terkandung dalam Tradisi Suran diantaranya nilai religius, nilai estetika, nilai gotong royong, nilai moral dan nilai toleransi. Kearifan lokal yang ada di tengah-tengah kehidupan masyarakat terwujud dalam bentuk seperangkat aturan, pengetahuan, keterampilan serta tata nilai dan etika. Ciri yang melekat pada kearifan lokal adalah sifatnya yang dinamis, berkelanjutan dan dapat diterima oleh masyarakat (Thamrin, 2013). Kearifan lokal berada di kehidupan masyarakat dan terus berkembang dari generasi ke generasi. Jadi keberadaan kearifan lokal menjadi pilar penting bagi terciptanya harmoni hubungan antar masyarakat.

Kearifan lokal hampir dimiliki oleh semua suku yang tersebar di seluruh penjuru Indonesia. Bahasa setiap daerah yang berbeda-beda sehingga penyebutan kearifan lokal juga berbeda, tetapi maknanya hampir sama yakni tidak terlepas dari pelajaran yang positif dalam kehidupan masyarakat (Aslan, 2017). Selain itu, kearifan lokal ini adalah sebuah produk budaya yang diciptakan oleh nenek moyang kita, sehingga menjadi warisan leluhur yang perlu kita kaji kembali dari segi maknanya. Nilai kearifan lokal merupakan nilai-nilai yang masih dipertahankan dan diaplikasikan dalam kehidupan masyarakat sehari-hari untuk kemudian diwariskan kepada generasi selanjutnya. Nilainilai kearifan lokal sangat berguna bagi masyarakat, baik secara kelompok maupun perorangan guna menciptakan kehidupan masyarakat yang diliputi kebaikan, kedamaian, keakraban, kebersamaan, dan saling pengertian (Hilmi, 2015). Nilai-nilai kearifan lokal berpacu pada perilaku bijaksana yang bersifat turun temurun, sehingga akan berbeda antar daerah satu dengan daerah yang lain.

Nilai kearifan lokal merupakan nilai-nilai yang masih dipertahankan dan diaplikasikan dalam kehidupan masyarakat sehari-hari untuk kemudian diwariskan kepada generasi selanjutnya. Adapun beberapa nilai kearifan lokal yang terdapat pada Tradisi Suran yang pertama, nilai religi adalah nilai yang terkait dengan hubungan antara manusia dengan Tuhan YME. Nilai religi merupakan segala sesuatu tersurat maupun tersirat yang ada dalam agama yang mempengaruhi perilaku seseorang dalam menganut agama (Rifa'i, 2016). Nilai religius mempunyai sifat hakiki dan datang dari Tuhan YME dan juga kebenarannya diakui mutlak oleh penganut agama tertentu. Nilai religius tampak dalam setiap do'a yang ditujukan kepada Tuhan YME, baik dalam latihan maupun pagelaran untuk memohon kelancaran dan dijauhkan dari hambatan.

Nilai selanjutnya adalah nilai estetika atau nilai keindahan sering dikaitkan dengan benda, orang dan peristiwa yang dapat menyenangkan hati (perasaan). Nilai estetika adalah nilai yang berkaitan dengan nilai indah atau jelek yang diberikan oleh seni. Nilai tersebut memiliki sistem yang secara bersamaan menyatu dengan gagasan, tindakan, dan hasil karya. Kemudian, nilai gotong royong yang merupakan merupakan kegiatan 
yang dilakukan secara bersama-sama dan bersifat suka rela dengan tujuan agar kegiatan yang dikerjakan dapat berjalan dengan lancar, mudah dan ringan (Rahman, 2016). Nilai gotong royong adalah nilai yang muncul bentuk kerja-sama kelompok masyarakat untuk mencapai suatu hasil positif dari tujuan yang ingin dicapai secara mufakat dan musyawarah. Nilai gotong royong tercermin pada kerbergantungan antar individu, kebersamaan, musyawarah, dan kerjasama

Nilai kearifan lokal yang selanjutnya adalah nilai moral yang merupakan nilai mengatur tindakan individu dalam membedakan baik dan buruk dalam hubungannya antar individu dalam masyarakat. Moral yang dimiliki individu tercermin dalam sikap jujur, suka menolong, adil pengasih, kasih sayang, ramah dan sopan. Sanksi bagi individu yang tidak menerapkan nilai moral adalah teguran, caci maki, pengucilan bahkan hingga pengusiran dari masyarakat. Nilai moral yang ada di kehidupan masyarakat dibagi menjadi dua bentuk, diantaranya nilai moral vertikal dan nilai moral horizontal. Nilai moral vertikal adalah hubungan yang terjalin secara spiritual yakni antara manusia dan Tuhan. Selanjutnya, nilai moral horizontal adalah hubungan positif yang terjalin antara manusia dengan manusia, manusia dengan hewan dan manusia dengan alam.

Nilai kearifan lokal yang terakhir adalah nilai toleransi yang mengacu pada sikap terbuka, lapang dada, dan suka rela dalam menghadapi perbedaan. Nilai toleransi merupakan nilai yang didasarkan pada kedamaian, menghargai perbedaan dan kesadaran. Toleransi diartikan sebagai sikap saling menghormati, saling menerima, dan saling menghargai di tengah keragaman budaya. Toleransi dalam kehidupan bermasyarakat memiliki dua bentuk, yaitu toleransi agama dan toleransi social (Nisvilyah, 2013). Toleransi agama adalah sikap lapang dada dalam memberi kesempatan setiap individu untuk agama yang benar-benar diyakini. Selanjutnya, toleransi sosial adalah sikap saling menghargai antar individu atau kelompokkelompok dalam masyarakat. Toleransi harus didukung oleh cakrawala pengetahuan yang luas dan bersikap terbuka. Toleransi yang diimplementasikan dengan baik dalam kehidupan sehari-hari akan mengantarkan kedamaian antar individu dalam hidup bermasyarakat.

\section{Metode}

Fokus penelitian ini adalah Nilai-Nilai Kearifan Lokal Kearifan Lokal Tradisi Suran di Desa Wonosari Kecamatan Wonosari Kabupaten Malang. Maka untuk memperoleh dan mengumpulkan data, penelitian ini menggunakan pendekatan kualitatif dengan jenis penelitian deskriptif. Tempat penelitian di Desa Wonosari, Kecamatan Wonosari, Kabupaten Malang. Data penelitian didapatkan melalui sumber primer dan sekunder, sumber primer diperoleh dari informan kunci dan pendukung sedangkan sumber 
sekunder diperoleh melalui informan kunci. Data primer diperoleh dengan melakukan wawancara langsung kepada informan. Sumber data primer dalam penelitian ini dipilih menurut kesesuaian tema yang diambil, yaitu terdiri dari informan pendukung dan informan kunci. Informan pendukung merupakan informan yang membantu penelitian untuk mengetahui secara garis besar sebelum masuk pada informan kunci.

Teknik pengumpulan data dalam penelitian ada tiga, yaitu wawancara, observasi, dan dokumentasi. Aktivitas menganalisis data menggunakan analisis data menurut Miles \& Huberman (2014) yaitu pengumpulan data, reduksi data, penyajian data, dan kesimpulan atau verifikasi. Tahap-tahap penelitian yang dilakukan ada 3, yaitu pra lapangan, pekerjaan lapangan dan pelaporan. Tahap pra lapangan dilakukan sebelum peneliti melakukan penelitian di lapangan, diantaranya, menyusun rancangan penelitian, melakukan observasi awal lokasi penelitian, mempelajari buku ataupun jurnal literatur lain yang berhubungan dengan fokus penelitian, menyusun proposal serta instrumen penelitian, melakukan seminar proposal dan mengurus surat izin penelitian. Tahap pekerjaan lapangan dilakukan peneliti dengan mengumpulkan data baik melalui observasi, wawancara dan dokumentasi. Selanjutnya tahap terakhir adalah pelaporan, Tahapan penelitian ini dilakukan setelah data dikumpulkan disesuaikan dengan fokus penelitian yang telah ditentukan.

\section{Hasil dan Pembahasan}

Masyarakat memiliki pedoman hidup yang diturunkan dari zaman nenek moyang yang dikenal dengan kearifan lokal (local wisdom). Kearifan lokal disampaikan antar generasi secara lisan, dari orang ke orang dan berbentuk kisah-kisah, legenda-legenda, dongeng-dongeng, upacara agama, lagu- (Siswanto, Pendidikan Karakter Berbasis Nilai-Nilai Religius, 2013) lagu serta hukum (Abbas, 2015). Salah satu kearifan lokal tersebut berbentuk tradisi, didalamnya terkandung beberapa nilai, diantaranya adalah nilai religi, nilai estetika, nilai gotong royong, nilai moral dan nilai toleransi. Pedoman hidup manusia baik untuk kehidupan di dunia maupun di akhirat yaitu berupa nilai religi. Nilai tersebut mengacu pada nilai-nilai dasar yang diajarkan dalam suatu agama. Nilai religi yang terkandung dalam tradisi tercermin saat doa secara khusyuk dipanjatkan kepada Tuhan YME. Ketika doa dipanjatkan, masyarakat berdoa dengan suasana yang khidmat untuk menyampaikan harapan-harapan di tahun berikutnya, sesuai agama dan kepercayaan masing-masing. Nilai religi yang terdapat dalam tradisi tercermin ketika masyarakat berdoa dengan hati yang ikhlas dan berharap akan datangnya kebaikan serta memohon dijauhkan dari berbagai musibah yang bisa terjadi kapan saja. Dalam kehidupan bermasyarakat, agama tidak akan tersebar tanpa budaya, begitu pula sebaliknya budaya akan tersesat tanpa agama. 
Valencia Tamara Wiediharto, I Nyoman Ruja, Agus Purnomo

Nilai-Nilai Kearifan Lokal Tradisi Suran

Keindahan suatu objek berkaitan dengan nilai estetika. Nilai tersebut membahas tentang seni dan keindahan serta tanggapan manusia terhadapnya, kepekaan terhadap seni dan keindahan (Nurmalinda, 2017). Nilai estetika atau keindahan yang terkandung dalam tradisi terlihat dari ragam bentuk dan hiasan pada tahap pelaksanaan tradisi. Nilai keindahan adalah realitas yang dapat membangun makna Apabila suatu obyek memiliki nilai keindahan, maka makna dapat terbangun dengan baik. Nilai gotong royong melekat dengan erat pada kehidupan masyarakat sehari-hari, umumnya tercermin dari beberapa kegiatan adat, seperti upacara adat, yang didalamnya terlihat keterlibatan masyarakat dalam awal, inti sampai kegiatan akhir upacara adat (Rolitia et al., 2016). Perilaku masyarakat yang saling bahu membahu dalam pelaksanaan tradisi mulai dari awal hingga akhir mencerminkan nilai gotong royong. Masyarakat secara sadar bersama-sama saling membantu satu sama lain apabila terdapat kesulitan dalam keseluruhan pelaksanaan tradisi. Jika sikap gotong royong telah menjadi suatu kesadaran, maka akan tercipta kerukunan dan kedamaian yang mengarahkan pada kestabilan dalam kehidupan bermasyarakat

Nilai moral menjadi panduan hidup masyarakat mengenai hal-hal yang perlu dilakukan dalam kehidupan sehari-hari. Nilai moral meliputi sikap kepatuhan, pemberani, rela berkorban, jujur, adil dan bijaksana, menghormati dan menghargai, bekerja keras, menepati janji, tahu balas budi, baik budi pekerti, rendah hati serta berhati-hati dalam bertindak. Nilai moral yang terkandung dalam tradisi terdermin dalam sikap teladan yang dicontohkan sesepuh desa dengan rutin menjalankan tradisi setiap tahun. Nilai moral ada dan tumbuh dalam diri tanpa paksaan dari luar dan bersumber dari kesadaran yang muncul pada diri masing-masing individu (Sabi'ati, 2016). Nilai toleransi tumbuh dengan baik dan mengakar pada kehidupan masyarakat yang terdiri atas berbagai macam suku, ras dan agama berbeda. Nilai toleransi terdapat pada sikap atau tindakan yang menghargai dan tidak melecehkan pihak lain ketika terdapat paham, pandangan dan keyakinan beragama yang berbeda (Tholkhah, 2013). Nilai toleransi yang terkandung dalam tradisi tercermin ketika seluruh masyarakat berkumpul tanpa adanya sikap membedakan latar belakang yang berbeda. Hal tersebut mampu memperkuat nilai toleransi dan menghadirkan sikap saling menghargai antar masyarakat. Menjadi pribadi yang toleran berarti menerima kehadiran keyakinan yang berbeda dan memberikan kebebasan orang lain menganut keyakinan yang telah dipilih (Anggraeni \& Suhartini, 2018:66).

Teori yang digunakan untuk mengkaji bentuk nilai-nilai kearifan lokal tradisi adalah teori interaksi simbolik. Teori interaksi simbolik merupakan proses berpikir mengenai interaksi antar individu dan ditandai oleh pertukaran simbol untuk mencapai suatu makna (Hutapea, 2016). Hal ini sesuai dengan pelaksanaan tradisi yang didalamnya terkandung nilai-nilai kearifan lokal meliputi nilai religi, nilai estetika, nilai 
gotong royong, nilai moral dan nilai toleransi. Hal ini serupa dengan pernyataan dari Bacthiar (2010) bahwa tiap individu dalam masyarakat berinteraksi dan pada akhirnya menghasilkan simbol-simbol yang bermakna sosial sama yakni berupa nilai-nilai kearifan lokal.

\section{Simpulan}

Perayaan 1 Suro untuk mengenang jasa dari dua tokoh berjasa pendiri Desa Wonosari, yaitu Eyang Djoego dan R.M Iman Soedjono. Tradisi Suran dilakukan sebagai ungkapan rasa syukur masyarakat Desa Wonosari atas berkah tanah yang subur pemberian dari Tuhan YME. Masyarakat Desa Wonosari memiliki cara-cara tersendiri untuk melestarikan tradisi yang ada di sekitarnya dan dikenal dengan kearifan lokal. Adapun kearifan lokal yang ada pada Tradisi Suran terbagi menjadi beberapa nilai, diantaranya nilai religi, nilai estetika, nilai gotong royong, nilai moral dan nilai toleransi. Nilai-nilai kearifan lokal tersebut merupakan simbol-simbol yang dihasilkan oleh masyarakat melalui proses interaksi. Nilai-nilai tersebut dapat dimaknai dengan baik apabila masyarakat menjalankan Tradisi Suran secara rutin setiap tahun dan memahami nilai-nilai yang terkandung dalam setiap tahapan mulai dari persiapan, pelaksanaan dan penutupan. Masyarakat Desa Wonosari juga diharapkan berperan secara aktif dalam pelaksanaan Tradisi Suran. Khususnya, untuk generasi muda agar tetap menjaga budaya lokal yang dimiliki Desa Wonosari agar tidak tergeser oleh budaya asing. Selanjutnya, peneliti menyarankan kepada peneliti selanjutnya untuk melakukan penelitian dengan menggunakan perspektif yang berbeda.

\section{Daftar Pustaka}

Abbas, E. W. (2015). Pendidikan IPS Berbasis Kearifan Lokal. WAHANA Jaya Abadi.

Aslan, A. (2017). Nilai-Nilai Kearifan Lokal dalam Budaya Pantang Larang Suku Melayu Sambas. Jurnal Ilmiah Ilmu Ushuluddin, 16(1), 11-20.

Bacthiar, W. (2010). Sosiologi Klasik Dari Comte hingga Parsons. Remaja Rosdakarya.

Hilmi, M. Z. (2015). Nilai-Nilai Kearifan Lokal Dalam Perilaku Sosial Anak-Anak Remaja di Desa Sepit Kecamatan Keruak Kabupaten Lombok Timur. Journal of Educational Social Studies, 4(1).

Hutapea. (2016). Identifikasi Diri Melalui Simbol-Simbol Komunikasi (Studi Interaksionisme Simbolik Komunitas Pemakai Narkoba di Dki Jakarta). Bricolage, 2 (1), 1-14.

Koentjaraningrat. (2016). Pengantar Ilmu Kebudayaan. Rineka Cipta.

Miles, \& H. (2014). Analisis Data Kualitatif. Terjemahan Tejetped Rohendi Rohidi. Universitas Indonesia (UI-Press).

Nisvilyah, L. (2013). Toleransi antarumat beragama dalam memperkokoh persatuan dan kesatuan bangsa (studi kasus umat Islam dan Kristen Dusun Segaran Kecamatan 
Valencia Tamara Wiediharto, I Nyoman Ruja, Agus Purnomo

Nilai-Nilai Kearifan Lokal Tradisi Suran

Dlanggu Kabupaten Mojokerto). Kajian Moral Dan Kewarganegaraan, 2(1), 382-396.

Nurmalinda, \& S. (2017). Makna Simbol Budaya Dan Nilai Estetika Pada Tradisi Perahu Baganduang di Desa Seberang Pantai Kecamatan Kuantan Mudik Kabupaten Kuantan Singingi Provinsi Riau. Jurnal Koba, 25-42.

Nurshodiq, N. (2012). TRADISI SURAN DALAM MASYARAKAT JAWA (STUDI PERBANDINGAN ANTARA WILAYAH SURAKARTA DENGAN WONOSOBO). Journal of Educational Social Studies, 1(1).

Rahman, A. (2016). Perubahan Budaya Bergotong Royong Masyarakat Di Desa Santan Tengah Kecamatan Marangkayu. Sosiatri-Sosiologi, 4 (1).

Rifa'i, M. K. (2016). Internalisasi Nilai-Nilai Religius Berbasis Multikultural Dalam Membentuk Insan Kamil. UIN Sunan Ampel Journal of Islamic Education, 4(1), 116-133.

Rolitia, M., Achdiani, Y., \& Eridiana, W. (2016). Nilai gotong royong untuk memperkuat solidaritas dalam kehidupan masyarakat kampung naga. SOSIETAS, 6(1).

Sabi'ati, A. (2016). Membangun Karakter AUD dalam Pengembangan Nilai Agama dan Moral di RA Masyithoh Pabelan Kab. Semarang. Al-Athfal: Jurnal Pendidikan Anak, 2(1), $1-14$.

Thamrin, H. (2013). Kearifan lokal dalam pelestarian lingkungan (the lokal wisdom in environmental sustainable). Kutubkhanah, 16(1), 46-59.

Tholkhah, I. (2013). Potensi Intoleransi Keagamaan Siswa Sekolah di Jawa dan Sulawesi. EDUKASI: Jurnal Penelitian Pendidikan Agama Dan Keagamaan, 11(1). 